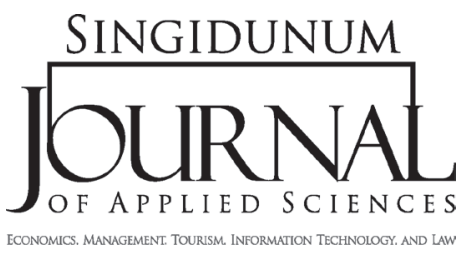

SINGIDUNUM JOURNAL 2012, 9 (1): 95-101

ISSN 2217-8090

UDK 316.74:2; 5:2

Review paper/Pregledni naučni rad

\title{
THE DIALOGUE BETWEEN RELIGION AND SCIENCE: TRUTHS, IDEAS AND BELIEFS ${ }^{1}$
}

\author{
ĐURO ŠUŠNJIĆ
}

Belgrade, Serbia

\begin{abstract}
:
Science and religion are two distinct but not two hostile paths: two ever valuable efforts of human spirit! Science and religion would have less intellectual disputes and social conflicts if only both of them would explicate their principles, and then in even dialogue, espy and evaluate possibilities and frontiers of their principles and sorts of enabled questions and answers. Religion might be interesting for science as it opens new and unknown fields of human experience. Frontiers of science and religion are historically changeable, which does not mean that they can escape. Religion is not a sort of less developed science, but an independent way of thinking, beliefs and actions, offering to believer a solution of some problems otherwise unsolvable, even by assistance of science and its methods.
\end{abstract}

\section{Key words:}

human development, independent thinking, social conflicts.

"The tremendous awakening, after the terrible earthquake, with new issues"

Between religion and science there is an old feud and hatred: even a collection of redundant insults could be made! With a few questions and answers, I will try to eliminate misunderstandings between them, for I believe that one should not renounce old truths in favour of new delusions. One such misconception is that science can solve all our problems - the misconception of scientism. A. N. Whitehead (Vajthed, 1976) said correctly: neither religion has always been wrong, nor has science always been right!
The importance of the question is of paramount importance for science, because only those who ask the right question can look forward to the correct answer. Here are just four questions about the relationship between science and religion which speak about the power as well as the weakness of science in the critique of religion.

If religion is an expression of ignorance, how come the progress in scientific knowledge cannot repress religion like ignorance? In other words: does religion weaken with the development of science?

1 This paper is the result of the lecture made for the Academy of Science, Montenegro (2007) and was published previosly in Glasnik Odjeljenja društvenih nauka 18 (1). 
If religious statements are scientifically false, why does $4 / 5$ of humanity still believe in them?

If religion is really an illusion, is reality which does not need illusions possible?

If faith is opposed to reason, how come most wise minds of science have not found contradictories between reason and faith?

Here are four answers to four questions in the same order in which questions followed one another.

If the scientific development threatened religion, then in societies where science is developed to the highest degree, there would be the smallest number of believers. And that, according to the data and ordinary experience, is simply not true, because in societies where science has been developed the most, we find the largest number of believers.

The question now is: where does the idea that religion is dying out along with the development of science? This idea could only arise from the analysis of empirical data on visiting religious services in churches. All the research shows there is a decline in the number of believers who perform religious rites in the church: the church is in the world, but the world is not in the church!

Of course, the empirical data on the number of believers who perform church rites does not lead to the conclusion that religion is dying out, but only that the church form of religious belief is weakening. For example, there are $83 \%$ of believers in Finland, and only $5 \%$ visit the church once a week. In England the ratio is 60:10, in Denmark it is 80:13 etc. What does this mean? This means that the performance of religious rites is not a sufficient proof of faith, because one can regularly perform a religious rite, and not believe, and some may believe, but not perform religious rites. St. Augustine already knew this when he said: God has many that the church does not have and the church has many that God does not have. It is better to be with God without the church than to be with the church without God!

Therefore, a believer can remain faithful to their god although they do not go to church, and vice versa. The number of those who believe is much larger everywhere than the number of those who perform religious rites in a church. Faith is transferred from the public to the private sphere: from the visible to the invisible faith, from an objective event to a subjective experience! There is not a crisis of faith and faith is not dying, it is just changing its form.
Therefore, the same faith can live in different ways. A lonely believer occurs more often: every man presents his own church, and every man presents his own pope. Religiousness is a broader term than churchliness, because there are also religious people outside church.

Today, the church must come to terms with the fact that it no longer represents the whole nation, but only a part of the flock of believers - it is no longer the conscience of the nation in the multiethnic and multicultural society. There is salvation outside the church as well, although the church still preaches the extra ecclesiam nulla salus. From now on, we will have to get used to not to seek religious feelings, ideas and values only in traditional, i.e. church forms of religion, but beside them, outside them, even against them (a monk, a mystic, a heretic, a sect, a cult and a denomination). The church is no longer the only meeting place of people and their gods. A religious relationship can not be reduced to church affiliation. The emergence of personal faith is evidence that a believer's choice is not finalized by his belonging to a religious institution. There is a wonderful saying: I live in a flock, but I hunt alone. Today it is even possible to choose God himself (Urlih, 2003).

A strong faith may not be a scientifically true faith. One belief does not have to be scientifically true, but it can satisfy some other needs. For example: when a tribe believes that a chatty woman will not have offspring, then women are reluctant to say much, so they are easier to be tolerated! Likewise, the belief that an evil spirit can enter a human being through their open mouth is not true, but it has a powerful influence on verbal behaviour of members of a community. This belief is certainly not true, but it makes sense, because it works, it is functional. Another example: a fairy tale is not true, but a fairy tale makes sense, because if it did not make sense, we would not tell it to our children and to each other. The fascist ideology is not scientifically true, but it makes sense, because if it had not, it would not have pulled such crowds. A lie is certainly not true, but a lie makes sense, because if it did not, people would not lie so much. The conclusion is clear: a true statement must make sense, a meaningful statement may not be true!

What does this mean with regard to our subject? This means that if a scientist denies the truth of theological statements, it does not mean that he denies the meaningfulness of religion. M. Hamilton 
(2003) often points out: If religious claims refer to the meaning of things, the question of their empirical confirmation is irrelevant. Some symbolical systems provide knowledge, other offer salvation. Joyous news of salvation may not be true, just like true news may not be joyous. If a doctor tells someone that they suffer from an incurable disease, then he told the truth, but the truth that kills. When you should tell the truth - it is advised by religious and moral standards. When you should not tell the truth - it is advised by experience and life. Standards are general, a decision is personal. Outside cognitive systems, the man is not concerned with the truth so much as he is with the salvation from the truth. Sometimes it does not matter if the answers to human suffering are true, it is important that they are comforting (Hese, 2006). There is so much evil in the world that every man needs a little hope and comfort. That is why even those who know a lot can believe: if faith once was the faith of the poor in spirit, there are signs that it becomes the faith of the rich in spirit! (Argil, 1975; Poinkare, 1989)

People evaluate their ideas and beliefs in at least two ways: gnoseologically and psychologically. A true idea can be rejected if it is unpleasant, and a false one can be accepted if it is pleasant. Truths are usually unpleasant. The doctor can tell his patient the truth which can make the patient die, but if instead of the truth he tells a noble lie, he might even help him. Psychologists express this in the following way: 1) What this man says seems true, but I find it uncomfortable, so I will not listen to him any more. 2) What this man says cannot be true, but I find it pleasant, so I will listen to him.

Problems posed by religion are not the ones which are solved by science. It has never solved them and it will never solve them! With religious ideas, beliefs and practices the man proves that for the questions, which he cannot provide a scientific answer for, he can offer an answer of another kind. In trouble, one does not look for a teacher, but a saviour. Scientists cannot solve problems that saints successfully solve. In this sense, religion is attractive for science in that it continually points to the limits of science and its methods: one lives on the imperfections of the other!

Science, as a form of rational thinking, which is aware of its limits, will not engage in issues that are beyond frames of rational solutions, since these are the issues of another type. The logic of reason is not the logic of faith. To delimitate means to prevent interference of one evaluation criterion with other forms of spirit. The reason, which is aware of its cognitive powers, is the mind, for it knows that it knows nothing of the occurrences that are beyond his cognitive power. "The use of reason in the debate about the holy is almost as meaningless as the attempt to eat soup with a fork. The existence of theology is only justified if it is completed with prayer and liturgy" (Armstrong, 2005).

The impotence of science opens up a vast field of religion. Science is a limited view of the world, which means that the wholeness of the world has never been and cannot be a subject of science. The man has a strong need to know the whole, that is, to connect his scattered information into one system. This is just what religion offers to him. For the truth is the whole. When the whole breaks into pieces, there is no more whole, or truth. Lao Tzu said a long time ago: Separate a cart into parts - and there is no more cart. God is a symbol of the synthesis of all our knowledge into one whole. F. Nietzsche has a right to shout: We infinitely yearn to be whole. In addition, science constantly changes its view of the world and many scientific truths have been proven wrong. S. Freud pointed out: the latest misconception in science is called the truth. Religious systems, by contrast, are not prone to changes. Lao Tzu warned that one should steer clear of science, because it is an endless quest, a never-ending adventure.

Science explains and understands some facts with the help of its rational concepts, theories and methods. All that is not possible to explain and understand in a rational way, it declares an illusion - it does not exist for it. Only what you can observe is a fact, and what cannot be observed is an illusion from the viewpoint of science. Science is a form of thought; religion is a way of life. No one has ever prayed to God in a scientific language. What the scientific language names an illusion is perhaps only a layer of the mystery of life, the mystery which is as real as life itself, but it remains unreachable and incomprehensible to the scientific language. K. Jaspers says well: The world in the consciousness is not everything at all. I. Kant in The Critique of Pure Reason saw far ahead: I had to abolish knowledge to get a place for faith. E. M. Remarque added: May the little jungle in us be blessed.

If religion is an illusion, how was it possible that all societies known to us had a religion, and how has the illusion been able to survive through the centuries, alongside with rational responses to 
environmental and social challenges? If religion is an illusion, how was it possible for the illusion to become socially recognized and obligatory as a way of symbolizing collective experience? It is an illusion to believe that one can live without an illusion. In a world without illusions, the man is a stranger, Albert Camus pointed out.

How can an original system of beliefs, ideas and practices be regarded as a collective delusion, if it met socio-psychological and other needs and desires of the man? How is it possible that these misconceptions have lived for so long and survived all the external changes in nature and in society if they have not satisfied the emotions, intellect and will of people? It would be too much even for one misconception to last as long as the man himself: if a delusion lasted for so long, then the man himself would be a delusion!

A human being can feel and experience what he cannot understand and explain. They cannot explain a dream, but a dream is a reality too. Freud pointed out that "the robbers in a dream are not real, but the fear is real", for one may die of this fear. All that acts, that is, that causes effects is real, regardless of its origin being sensory or supersensory, apparent or non-apparent, visible or invisible. Someone, I do not know anymore who, said: The question is not of whether what appears is real, but which layer of reality it belongs to, because if it did not belong anywhere, it could not appear. So the man of science, which explores faith, meets with the stratification of reality itself, gaining awareness not only of the limits of scientific knowledge, but also of the infinity of the world. The analytical method breaks with different approaches to reality, but it also confines itself to a fuller understanding of reality. For the scientific method, the existence of a secret is only a proof of ignorance. For science, everything, which is impossible to be explained in rational terms, is mystical.

J. Gaarder (Gorder, 1996), in his work Sophie's World, recounts the following event: on one occasion a Russian astronaut and a Russian neurosurgeon discussed religion. The neurosurgeon was a great believer and the astronaut was a fierce unbeliever. "I was in space many times," the astronaut bragged, "but I never met either God, or angels." - "And I operated on many smart brains", - the neurosurgeon replied, "but I have never seen a single thought."
Confucius said: There is nothing more obvious than what eyes cannot see and nothing more tangible than what senses cannot feel. There exists not only what can be seen, but what cannot be seen as well. The thought cannot be seen, but it exists. The force of gravity exists, but it is not visible. Radioactive radiation exists, even though it cannot be seen. Ivo Andrić, in Signs Near the Travel-road, says exactly: When I can not see, I will not watch. There is a difference between those who watch and those who see. Those who watch perceive only things; those who see penetrate their soul, their essence. Some phenomena exist only if we believe in them (future, love and God). If we do not believe in them, they do not exist for us. In addition to the systems of knowledge there are systems of belief.

If we could know everything, we would have nothing to believe in: we believe when we do not know! Eastern wise men say: The biggest part of what we know is the smallest part of what we do not know. It is not true that faith ends where reason begins, it is true that faith begins where reason ends. Where reason grows weary, faith encourages. Faith and reason are the two powers of the same soul. What we can not learn through reason we will not declare non-existent. The most reasonable peoples in our history believed in the most amazing things, which only proves that the mind can not be and is not a natural enemy of faith. Socrates was the most sensible citizen of the Athenian state, but he went to the oracle whenever he needed to make a crucial decision. Faith can also be reached in a reasonable way, and not just through experience, feelings and actions. Pascal's famous bet on God says: If you believe in God, and God does not exist, you lose nothing, but if you do not believe in God, and God exists, you can lose everything. Therefore, even from a purely logical and rational point of view, it is better to believe than not to believe.

Faith is the first contact with the other world: perhaps with the better part of ourselves, which we are usually unaware of. There are experiences that we cannot express with words and concepts, and yet, they are experiences of something or with something, because if they were not related to something - they would not exist. These are the so-called mystical experiences. Mystical here means only that they cannot be rationally explained and understood. This is something which is not expressible but is present, and it demands to be recognized: the unconscious darkness in us! Because one cannot claim 
that the experience of mystics is something empty, because every experience must be an experience of something. And when you keep silent about something, that something is nothing, just there are no words to say something, so it turns out that we are silent about nothing. Silence also points to something one is being silent about - silence can even be an eloquent speech.

We are closer to God when we are silent than when we talk about it. While we are silent, we suspect and keep a secret which cannot be put into words. By keeping silent we pay respect to the unutterable. We must be aware that both what is said and what is not said, i.e. the unutterable, which has to be testified by silence, are the truth. The expressible and the inexpressible create our experience together, so we can believe both those who speak and those who remain silent. Something expressible refers to something inexpressible. Religion knows best the limits of human expression - that is why a mystic keeps silent. We need a lot of talk and even more silence.

In deep mourning, when you bury someone close to you, not a single word can be heard. Even Aristotle observed that in such circumstances it is unwise to say anything, you can only move a finger. Any talk about it is just one more mistake. It is the experience beyond language, and therefore the experience has the advantage over knowledge. Cemetery is identified with silence which tells the man about himself: about his ultimate destiny and tranquility! The poet says well: Landscapes of our blood remain nameless. A concept and a word cannot express what a look and silence can. Two people in love create a community of looks and silence. There are experiences that are beyond language, unspeakable in any way. And when you try to express them, you meet insurmountable difficulties. When the feelings and thoughts are transferred into words and concepts, a betrayal always occurs.

A mystic does not lose interest in a mystery that will never be expressed through a language. A. F. Capra in The Tao of Physics said: Science does not need mysticism and mysticism does not need science; but the man needs both (Kapra, 1989; Gerc, 1989). Now it becomes clear that the so-called historical conflict between science and religion is a wrong understanding of both, because there is no conflict between them and there can not be one, if we draw a clear distinction between scientific and religious statements.
If we, as intelligent beings, agree that a part of our lives can be explained and understood in scientific terms and theories, we can also agree with the fact that a part of our lives resists the scientific method of thinking. In other words, life is partly clear, partly mysterious: at one moment it calms us, at another it disturbs us.

The science itself, which by its nature denies faith, is either indifferent to religion, or everything it handles is completed on the basis of religion. The search for the truth is based on a belief that there is the truth, just like the search for the meaning of life is based on a belief that life has a meaning. The statement that the thoughts of a scientist are founded means only that they are based on a certain assumption, which he believes to be productive although he does not know if it is true. Since his cognitions are based on the assumption adopted by faith, it follows that the cognitions are, in fact, beliefs and there is not a method with which they can be proven as completely certain. S. Kierkegaard says correctly: Faith is the rope which you must hang onto unless you want to hang yourself. Hugo would add: Everything hangs, but nothing falls. Empirical science cannot build a foundation in itself and is therefore forced to found itself on assumptions around it. As theology is based on a certain assumption, its destiny is shared by science as well. Science as organized skepticism harbours distrust towards a priori discovered or revealed truths, until it is convinced that it is based on these truths itself. Maybe science has the advantage of replacing one assumption with another, which is not possible in theology. In any case, since science as a system of knowledge is based on a system of belief, it is clear that it can not be a purely rational activity. Anselmo is right: I believe that I can understand.

\section{CONCLUSIONS}

The difference between scientific and religious statements can be found in the field of logic, since theological statements can be extremely logical, just like scientific ones (a good example is Thomas Aquinas). Illogicality can be taken as the first sign that it is not about scientific statements. E. Fromm warned that even paranoid thinking may be logical - logic does not rule out insanity. If false statements can be just as logical as truthful statements, then the difference between them cannot be found in the field of logic. In other words, true thinking has to be correct, correct thinking does not have to be true. Everything 
can be logical, nothing may be true. Logic teaches us the correct way of telling incorrect things. A lie can be presented in a logical manner, as well as all other misconceptions. Beware of logic, because it may, not necessarily, have to do with the truth. True knowledge does not necessarily have a logical form, because the truth can be found even in forms that are not purely logical, but perhaps theological or mythopoetic.

The difference between scientific and religious statements cannot be reduced to the difference between sense and nonsense, because theological statements are extremely meaningful, just like scientific ones. Statements about God, devil, angels, ghosts, etc. are not factual statements but evaluations, and therefore assessment criteria of statements about facts should not be applied to them. These are two lines of statements that should not be confused. Holy books are not sciences about the man, but instructions for his salvation. And no instructions spring out of empirical science. From the scientific analysis of free-falling body nothing can be concluded about the moral decline of the man. It is one thing to know the chemical composition of water, and the other to give a thirsty man to drink. The fact that a man is tall does not mean that he also has high moral values. Therefore: a statement about a fact and its evaluation talk about the same thing, but in different ways. Evaluations cannot be derived from facts, but they refer to facts. Because one thing is knowledge of the facts and the other is awareness of the value meanings: the former is useful for thinking, the latter is good for living. The former is, therefore, a fact and its significance for science and the latter is value and its importance for life.

It is wise to distinguish between significance and meaning. An event can be very significant regarding its socio-psychological consequences, and have no meaning or sense. One event may have no significance regarding its socio-psychological consequences, but has an exceptional meaning, because it is full of truth and sense. The events referred to in the Holy Scriptures are not important in themselves, but the significance or the meaning of these events (real, potential and imaginary) for believers and their lives are of utmost importance. These events could happen at any time and anywhere, even in imagination, which is completely irrelevant, because historical facts and historical time are not important, but superhistorical meanings and mythical time (the Greek philosophy and Roman law with their meanings defy time and are a slap in the face of time).
The difference between scientific and religious statements can not be determined even with respect to truthfulness, since both types of statements are true within their domains and criteria of truth which are valid in them. Only when theological statements refer to empirical facts, they can be verified, refuted, rejected or accepted by science, whereas in any other case, science cannot say anything about the value of such statements, even if they are true or not. Empirical science cannot say anything about superempirical meanings (Dokins, 2007). However, the dialogue between science and religion is enabled by the existence of rational dimension in both systems of ideas, beliefs and practices. Therefore, a critique of religion from the standpoint of science includes only the rational (cognitive, intellectual, logical and conceptual) layer of religion, that is, the dogmatic or rational theology, while other layers remain mostly beyond the reach of the criticism. A rational critique of religion cannot be successful to the same extent in which religion relies on irrational layers in the experience of a believer.

Science and religion are two different paths leading the man towards the truth about himself and the world he lives in. These are two different but, by no means, two hostile paths: two equally worthy efforts of human spirit! This mental and humane assumption about equality in the dialogue excludes all those points of view implying those religious ideas, beliefs and rituals on a lower level in the development of the man's relationship with the world and himself, and this level of development will be overcome when the man masters scientific methods of understanding and ruling the world and himself as well. Religion is a property of the human spirit, and not a lower level in its development. The man is an incurably religious being.

The difference between scientific and religious statements can only be found in the area of human needs and desires: scientific statements meet the need for rational knowledge; theological statements meet the needs beyond knowledge (the need for consolation, salvation, the ultimate meaning of life and death). Any belief which does not meet some human needs and desires is condemned to extinction. Religion is not extinct. It meets some permanent needs and desires. So, the future of religion does not depend on a rationalist critique of religion, or the development of rational theology, but the needs and desires of people and ways of solving their problems. Rationalism is far from understanding life: it is an offspring of a writing-desk. Religious faith should not be interpreted as irrational, but 
only as a different form of spiritual understanding and expression of our experience. Religion is not a science in its infancy, which will move to a museum when the science grows up, but it is an independent way of thinking, the beliefs and actions, in which a believer solves some of his problems, those that cannot be solved in other ways, including the support of science and its methods. Religion is not a form of underdeveloped science. If science led to disbelief, then scientists would all be nonbelievers, and that is simply not true.

Ultimate achievements in science, philosophy and art came from the ranks of scientists, philosophers and artists who were believers, in one way or another. Mohammed said: There are two things I abhor: a learned man who does not believe and a pious fool (Emerson, 1997).

If you forget everything I have said, I would like you to forget the last thing I am about to utter now. If one says that religion is a delusion, it has not been said to be a lie yet; if one says that it is not the truth, it has not been said not to make sense yet; if one says that it is an illusion, nothing has been said about its life value yet; if one says that it is old, it is not said to be outdated.

If this paper begins with the questions where all my hopes and doubts have been risen, it is understandable that I have not searched for the answers only in one direction and clearly defined. The philosopher of the will to power said: I'm too curious, too inquisitive, and too impetuous, to like a response as harsh as a fist.

\section{REFERENCES}

Argyle, M. (1975) The Social Psychology of Religion. London: Routledge.

Armstrong, K (2005). Kratka istorija mita. Belgrade: Geopoetika. (in Serbian)

Dokins, R. (2007) Zabluda o Bogu. Smederevo: Helios. (in Serbian)

Emerson, R.V. (1997) Upravljanje životom, Gornji Milanovac: Milprom. (in Serbian)

Gerc, K. (1989) Tumačenje kultura 1. Belgrade: XX vek. (in Serbian)

Gorder, J. (1996) Sofijin svet: Roman o istoriji filozofije. Belgrade: Geopoetika. (in Serbian)

Hamilton, M. (2003). Sociologija religije. Belgrade: CLIO. (in Serbian)

Hese, H. (2006) Umetnost dokolice. Belgrade: PolitikaNarodna knjiga. (in Serbian)

Kapra, F. (1989) Tao fizike: Jedno istraživanje paralela između savremene fizike $i$ istočnjačkog misticizma. Belgrade: Opus. (in Serbian)

Morli, D., Robins, K. (2003) Britanske studije kulture. Belgrade: Geopoetika. (in Serbian)

Poinkare, H. (1989) Znanost i hipoteza. Zagreb: Globus. (in Croatian)

Urlih B. "Živeti sopstveni život u svetu koji se ubrzano menja”. In: Hatton, W., Giddens, A. eds. (2003) Na ivici - živeti sa globalnim kapitalizmom. Belgrade: Plato. (in Serbian)

Vajthed, A.N. (1976) Nauka i moderni svet. Belgrade: Nolit. (in Serbian)

\section{DIJALOG IZMEĐU RELIGIJE I NAUKE: ISTINE, IDEJE I VEROVANJA}

\section{Rezime:}

Nauka i religija su dva različita, a nikako dva neprijateljska puta: dva podjednako vredna napora ljudskog duha. Nauka i religija bi imale manje intelektualnih sporova i društvenih sukoba kad bi samo obe objasnile svoje principe, a onda u dijalogu jednakih tražile i procenjivale mogućnosti i granice svojih principa i vrsta omogućenih pitanja i odgovora. Religija može biti zanimljiva za nauku, jer otvara nova i nepoznata područja ljudskog iskustva. Granice nauke i religije su istorijski promenljive, što ne znači da mogu da nestanu. Religija nije neka vrsta manje razvijene nauke, nego nezavisan način razmišljanja, verovanja i delanja, koja verniku nudi rešenja nekih problema koji su inače nerešivi, čak i uz pomoć nauke i njenih metoda.

\section{Ključne reči:}

ljudski razvoj, nezavisno mišljenje, društveni konflikti.

Received: May 27th, 2011 Correction: July 15th, 2011 Accepted: August 4th, 2011 